\title{
Flow alteration impacts on Hudson Bay river discharge
}

\author{
Stephen J. Déry ${ }^{1,2}$ (D) । Tricia A. Stadnyk ${ }^{1,2}$ (D) । Matthew K. MacDonald ${ }^{1,2}$ (D) । \\ Kristina A. Koenig ${ }^{3}$ (D) । Catherine Guay ${ }^{4}$ (D)
}

${ }^{1}$ Environmental Science and Engineering Program, University of Northern British Columbia, Prince George, British Columbia, Canada

${ }^{2}$ Department of Civil Engineering, University of Manitoba, Winnipeg, Manitoba, Canada

${ }^{3}$ Hydrological Sciences Division, Manitoba Hydro, Winnipeg, Manitoba, Canada

${ }^{4}$ Hydro-Québec, Institut de Recherche d'Hydro-Québec, Varennes, Québec, Canada

Correspondence

Stephen Déry, Environmental Science and Engineering Program, University of Northern British Columbia, Prince George, British Columbia V2N 4Z9, Canada.

Email: sdery@unbc.ca

Funding information

Natural Sciences and Engineering Research Council of Canada; Manitoba Hydro, Grant/ Award Number: Baysys project

\begin{abstract}
This study explores flow regulation controls on daily river discharge variations and trends into Hudson Bay from four highly regulated and 17 moderately regulated/ unregulated systems over $1960-2016$. These 21 rivers contribute $\sim 70 \%$ of the total annual riverine freshwater export to Hudson Bay, with highly regulated and moderately regulated/unregulated rivers accounting for $47 \%$ and $53 \%$ of the discharge, respectively. Daily observed streamflow data from the Water Survey of Canada, Manitoba Hydro, Ontario Power Generation, and Hydro-Québec are used. Decadal hydrographs of the mean and coefficient of variation of daily river discharge are developed to assess the changing hydrological regimes in both systems. Decadal spectral analyses reveal the dominant controls on daily river discharge input to Hudson Bay from the regulated and unregulated systems. Apart from expected peaks in spectral power on annual timescales arising from the nival regimes in both systems, a strong secondary peak emerges at weekly timescales from flow regulation due to hydropower production. Hydrographs that consider the day of the week reveal distinct weekly cycles in regulated rivers with $~ 10 \%$ declines in daily river discharge during weekends and statutory holidays relative to weekday averages, demonstrating the importance of regulation on the timing of freshwater into Hudson Bay.
\end{abstract}

\section{KEYWORDS}

climate change, flow regulation, Hudson Bay; James Bay, hydropower, pan-Arctic river discharge, streamflow, water resources

\section{1 | INTRODUCTION}

Hudson and James Bays form a large inland sea spanning $8.4 \times 10^{5} \mathrm{~km}^{2}$ in northern Canada that receives $\sim 760 \mathrm{~km}^{3}$ year $^{-1}$ of freshwater from terrestrial rivers (Macdonald \& Kuzyk, 2011). This large influx of freshwater affects the physical (e.g., temperature and density), chemical (e.g., salinity), and biological (e.g., nutrients and contaminants) states of Hudson Bay waters. Hudson and James Bays capture this freshwater from a drainage basin spanning $3.7 \times 10^{6} \mathrm{~km}^{2}$ or about one third of the Canadian landmass (Figure 1). This includes some of Canada's largest rivers by annual discharge to the coastal ocean, including the La Grande Rivière, Moose, and Nelson/Churchill Rivers. Through recent interbasin diversions, the Nelson River and La Grande Rivière now rival British Columbia's Fraser River as Canada's third largest by annual flows after the Mackenzie and St. Lawrence Rivers and rank among North America's top 10 (Benke \& Cushing, 2010).

Given their voluminous flows equating nearly half of the total gauged discharge to Hudson Bay, La Grande Rivière, the Moose, and Nelson/Churchill Rivers and their major tributaries have long been harnessed for their hydroelectric potential. As such these waterways are now strongly affected by fragmentation and flow alteration (Dynesius \& Nilsson, 1994). This includes development of the massive James Bay hydroelectric complex centred on the La Grande Rivière system that became fully operational in the early 1980 s to supply rapidly growing demands for electricity in the province of Québec. Continued development ensued in the 1990s and 2000s with the addition of several generating stations and further diversions of nearby rivers. In Ontario, a total of 10 generating stations on the 


\section{Major watersheds of Hudson Bay}

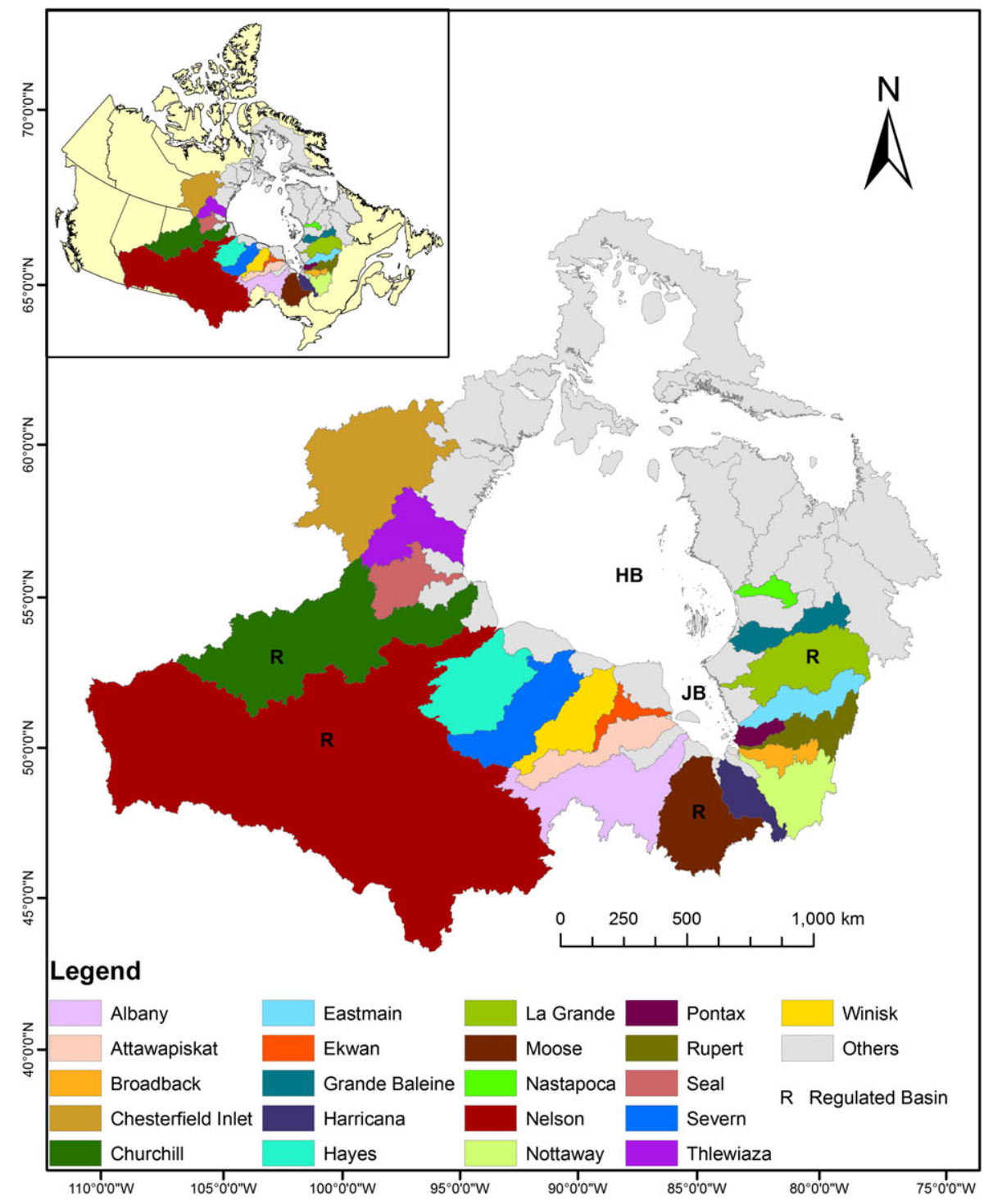

FIGURE 1 Map of the Hudson Bay drainage basin including the regulated $(R)$ and unregulated rivers used in this study

Mattagami and Abitibi Rivers, two main tributaries of the Moose River, entered into operation since the 1910s. Similarly, development of hydroelectric facilities on the main stem Nelson River began in earnest during the 1960s and now comprises six generating stations (including one (Keeyask) currently under construction) feeding Manitoba's needs for electricity.

With increasing demands for electricity in North America and the continued expansion of hydropower facilities in the Nelson/Churchill, Moose, and La Grande Rivière systems, discharge in these rivers has likely evolved towards a more altered state since the 1960s. Indeed, past efforts reported an attenuation of the seasonal cycle of river discharge into Hudson and James Bays through water retention in large natural and artificial reservoirs for hydropower production during peak demand periods, most often in winter and summer for domestic, commercial, and industrial climate control (heating and cooling; Anctil \& Couture, 1994; Déry, Mlynowski, Hernández-Henríquez, \& Straneo, 2011; Prinsenberg, 1980). These flow alterations reflect patterns observed across North America including the boreal pan-Arctic domain (Woo, Thorne, Szeto, \& Yang, 2008). Indeed, the "flattening" of hydrographs, changes in the seasonality, and reductions of peak flows have been observed in the Columbia River (Naik \& Jay, 2011), the Peace/Mackenzie River (Bring et al., 2016; Leconte, Pietroniro, Peters, \& Prowse, 2001; Peters \& Buttle, 2010; Peters \& Prowse, 2001; Rosenberg et al., 1997), and most regulated rivers of southern Québec (Assani, Stichelbout, Roy, \& Petit, 2006; Lajoie, Assani, Roy, $\&$ Mesfioui, 2007). In extreme cases such as the Peace River just downstream of the WAC Bennett and Peace Canyon dams, regulation can reverse flow seasonality, producing higher flows in winter when hydropower demand peaks, and lower flows in spring during the historical (preregulation) timing of the snowmelt-driven freshet (Peters \& Prowse, 2001; Woo et al., 2008). Thus, the objective of this study is to assess how water management for hydropower production affects daily variations and seasonal trends in streamflow input into Hudson Bay from four of its highly regulated waterways (i.e., La Grande Rivière, Moose, and Nelson/Churchill Rivers) in comparison with a set of 17 mostly unregulated rivers (waterways with moderate or no levels of fragmentation [Dynesius \& Nilsson, 1994]) with nearly equivalent total annual discharge into Hudson Bay. To that end, the 
1960-2016 observed discharge data along the main stem of these rivers are used to calculate the decadal patterns of the mean and coefficient of variation of daily flows. Spectral analyses inferred from discrete Fourier transforms are also employed to reveal the dominant timescales of cyclicity in river flows. Following the results, the discussion provides further interpretation and implications of the study's main findings whereas the conclusion summarizes our key findings, places the study in a broader context, and outlines future research opportunities.

\section{2 | STUDY AREA}

\subsection{Major rivers of the Hudson Bay drainage basin}

The Hudson Bay drainage basin covers a vast area of north-central Canada with a portion residing in the northern United States (Figure 1). Its four largest rivers by volumetric flows are the Nelson River and La Grande Rivière, each now exceeding annual discharge rates of $100 \mathrm{~km}^{3}$, the combined Thelon and Kazan Rivers (collectively referred to as Chesterfield Inlet) and the Moose River, both with annual discharge rates of $\sim 40 \mathrm{~km}^{3}$ (Déry, Stadnyk, MacDonald, \& Gauli-Sharma, 2016). Prior to its partial diversion to the Nelson River, the Churchill River's annual discharge of $\sim 37 \mathrm{~km}^{3}$ made it the fifth largest Hudson Bay river by annual flows. The headwaters of the Nelson River lie in the Canadian Rockies within the Saskatchewan River Basin, with its other major tributaries being the Assiniboine, Winnipeg, and Red Rivers. The main stem Nelson River begins at the outlet of Lake Winnipeg, in north-central Manitoba, from which it flows northeastward towards Hudson Bay. Its gross basin area (prior to the diversion of the nearby Churchill River) totals $1.1 \times 10^{6} \mathrm{~km}^{2}$. The main stem Churchill River originates from Churchill Lake in north-western Saskatchewan draining a vast $\left(2.8 \times 10^{5} \mathrm{~km}^{2}\right)$ network of lakes and wetlands of the Canadian Shield and then Arctic tundra near its mouth into Hudson Bay at Churchill, Manitoba. The Moose River forms at the confluence of the Mattagami and Missinaibi Rivers of north-eastern Ontario with the Abitibi, Kwetabohigan, and North French Rivers augmenting downstream flows prior to discharging into James Bay. The headwaters of La Grande Rivière lie in the Otish Mountains of north-central Québec with the river's main stem flowing westward to reach James Bay near Chisasibi. Major tributaries for La Grande Rivière are the Sakami, de Pontois, Kanaaupscow, and Laforge Rivers, with the basin covering $9.7 \times 10^{4} \mathrm{~km}^{2}$ prior to diversions from adjacent rivers. In total, the highly regulated rivers draining to Hudson Bay span a gauged area of $1.6 \times 10^{6} \mathrm{~km}^{2}$ excluding the basins partially diverted into the La Grande Rivière system.

Largely unregulated rivers draining into Hudson Bay collectively span a gauged area of $9.0 \times 10^{5} \mathrm{~km}^{2}$ and include Nunavut's Thelon, Kazan and Thlewiaza Rivers, Manitoba's Seal and Hayes Rivers, Ontario's Severn, Winisk, Attawapiskat and Albany Rivers, and Québec's Grande Rivière de la Baleine, Broadback and Nottaway Rivers. Although listed in this group, the Grande Rivière de la Baleine, Nottaway, and Albany Rivers remain moderately fragmented by minor dams and/or partial diversions (Dynesius \& Nilsson, 1994). The gauged data for Québec's Eastmain and Rupert Rivers also reflect their partial diversions into the La Grande Rivière system in 1980 and 2008, respectively, resulting in a net transfer of discharge from the unregulated to regulated rivers during the study period. Nonetheless, this study retains both the Eastmain and Rupert Rivers in the set of 17 mostly unregulated rivers to characterize their unaltered flows prior to their northward deviations to the La Grande Rivière system and then downstream of diversion points postregulation. Daily discharge data for La Grande Rivière also exhibit a stepped increase in flows starting in January 1984 when $\sim 21.0 \mathrm{~km}^{3}$ year $^{-1}$ of the upper Caniapiscau River was diverted from its usual course to Ungava Bay to this system (Roy \& Messier, 1989).

\section{2 | Development of hydroelectric facilities on Hudson Bay rivers}

Although construction of hydroelectric facilities on tributaries of the Nelson River commenced in the early 20th century (Déry et al., 2016), development along its main stem only began in the early 1960s. The Kelsey, Kettle, Long Spruce, and Limestone generating stations on the main stem Nelson River first became operational in 1961, 1970,1977 , and 1990 , respectively, with the addition of the upstream Jenpeg combined control and generating station in 1979 (Table 1; Manitoba Hydro, 2017a). In 1976, the Churchill River in northern Manitoba was diverted southward into the Rat and Burntwood Rivers to enhance power production on the lower Nelson River, effectively increasing the catchment area of the Nelson River by $2.7 \times 10^{5} \mathrm{~km}^{2}$. The Notigi control structure on the Rat River regulates transfers from the Churchill River Diversion (CRD) with further minor flow alterations on the Burntwood River at the Wuskwatim power plant, which became operational in 2012. The total hydroelectric capacity of these six generating stations presently equals 4,149 MW (Manitoba Hydro, 2017a). Natural reservoirs in this system include Lake Winnipeg (seasonal storage) and Stephens Lake (weekly storage) that are managed differently according to their storage capacity, downstream hydropower production, operational rules, flood protection, ecological flows, and other considerations. Water releases from Lake Winnipeg reach all five existing Manitoba Hydro generating stations on the Nelson River whereas those from the CRD through Stephens Lake reach only the Kettle, Long Spruce, and Limestone hydropower plants before emptying into Hudson Bay.

Development of the hydroelectric potential in the upper reaches of the Moose River Basin began in the early 1910s with the commissioning of the Sandy Falls and Wawaitin generating stations on the Mattagami River (Table 1; Ontario Power Generation, 2017). Since then, five additional generating stations came online between the 1930 s and 1960s bringing the total generating capacity on the Mattagami River to $959 \mathrm{MW}$. Hydroelectric facilities were also built along the Abitibi River starting in 1933 with the Abitibi Canyon generating station followed by the Otter Rapids and Peter Sutherland Sr. generating stations in 1961 and 2017, respectively, for a combined generating capacity of 559 MW. Nonetheless, the main stem Moose River and three of its other major tributaries, the Missinaibi, North French, and Kwetabohigan Rivers covering $3.4 \times 10^{4} \mathrm{~km}^{2}$, remain not affected by fragmentation. Combined with the limited storage capacity behind hydroelectric dams on the Mattagami and Abitibi Rivers, the Moose 
TABLE 1 Information on the principal dams at hydroelectric generating stations or control structures (listed chronologically for each river) and associated reservoirs for the regulated systems in this study

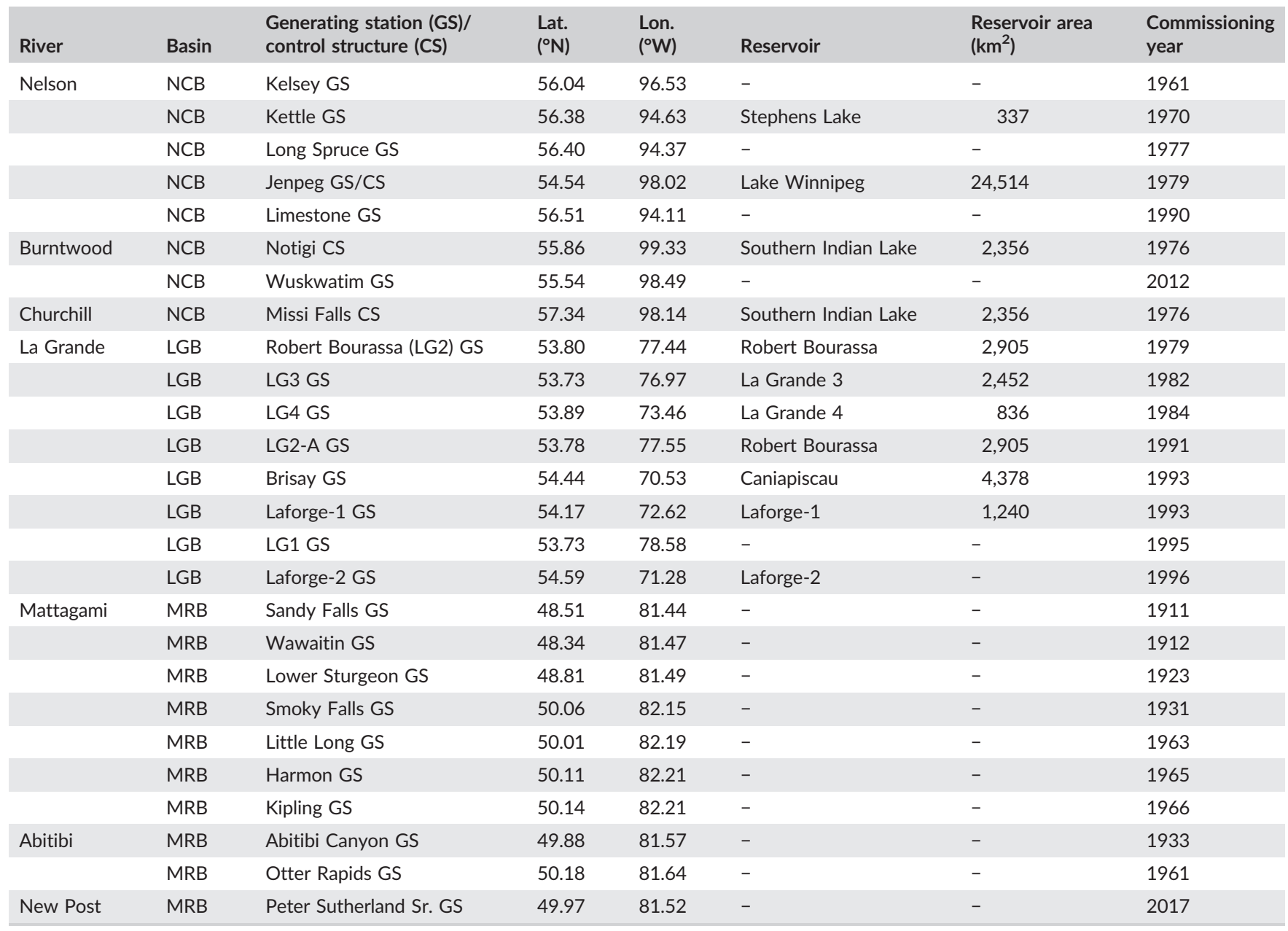

Note. A "-" denotes run-of-river generating stations with minimal storage capacity and hence no reservoirs. LGB: La Grande Rivière Basin; MRB: Moose River Basin; NCB: Nelson/Churchill Basin.

River consequently exhibits less impact from flow alteration than the Nelson/Churchill Rivers and La Grande Rivière.

Construction of the James Bay hydroelectric complex along the main stem La Grande Rivière by Hydro-Québec began in the mid1970s (Hernández-Henríquez, Mlynowski, \& Déry, 2010). Among its other active sites, the Robert-Bourassa (formerly LG2), LG2-A, and LG1 generating stations, the three furthest downstream on La Grande Rivière, were commissioned in 1979, 1991, and 1995, respectively (Table 1; Hydro-Québec, 2017). Flows of the adjacent Eastmain/ Opinaca, Caniapiscau, and Rupert Rivers were diverted starting in 1980, 1982, and 2009, respectively, to enhance power production at the James Bay hydroelectric complex, effectively doubling the catchment area of La Grande Rivière (Hydro-Québec, 2008; Roy \& Messier, 1989). Since the initial development phase, additional generating stations with reservoirs were built along diverted rivers to enhance the generating capacity of the James Bay hydroelectric complex. Large reservoirs, with a capacity exceeding $200 \mathrm{~km}^{3}$, have also been developed to store water seasonally (Déry et al., 2016; Déry, Stieglitz, McKenna, \& Wood, 2005). As of January 1, 2016, the installed generating capacity of the James Bay hydroelectric complex totals 17,418 MW (Hydro-Québec, 2017), second only to China's Three Gorges Dam in capacity (cf 22,500 MW; USGS, 2017).

\section{3 | DATA AND METHODS}

\section{1 | Data}

This study focuses on 21 of the largest rivers (by volume) with outlets into Hudson and James Bays. The study period spans January 1, 1960 to December 31, 2016 inclusively for which extended records of daily hydrometric data are available for all rivers. For all unregulated rivers and the period prior to some of the hydroelectric development along the main stem and tributaries of La Grande Rivière, the Moose and Nelson/Churchill Rivers, daily discharge data are sourced from the Water Survey of Canada (2017). After hydroelectric development, daily discharge data are collected and quality controlled in part by Manitoba Hydro for the Nelson/Churchill Rivers, Ontario Power Generation for the Mattagami and Abitibi Rivers, and Hydro-Québec for La Grande Rivière. Gauges furthest downstream on a river's main stem are selected to capture flow regulation on freshwater input to Hudson and James Bays (Table 2). Daily hydrometric data above Bladder Rapids (January to June 1960), and the Kelsey (July 1960 to December 1970), Kettle (December 1970 to September 1977), Long Spruce (October 1977 to September 1990), and Limestone (October 1990 to December 2016) generating 
TABLE 2 Information on the hydrometric stations used for the regulated systems in this study

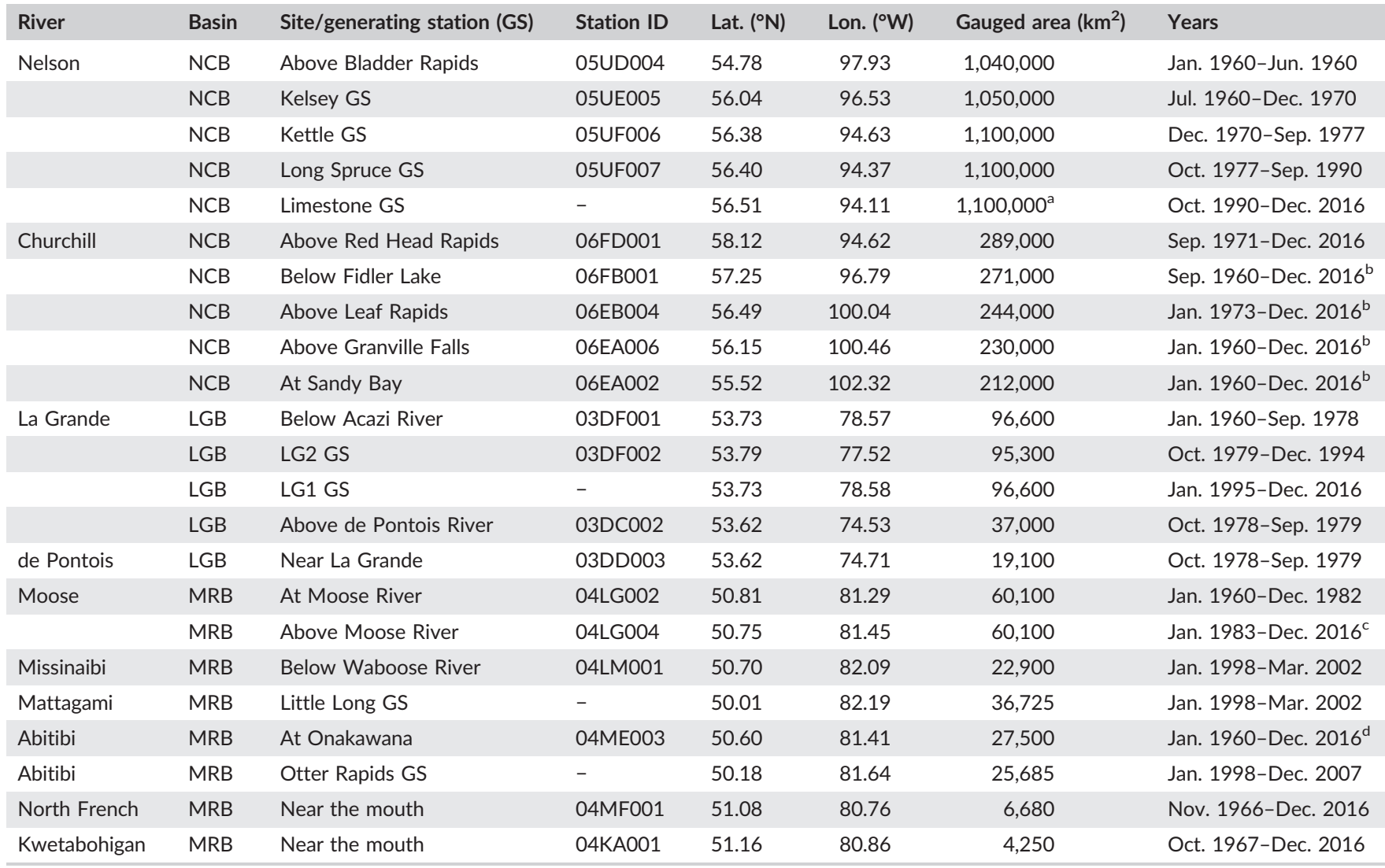

Note. LGB: La Grande Rivière Basin; MRB: Moose River Basin; NCB: Nelson/Churchill Basin.

aEstimated values.

bUsed only to in-fill temporal gaps for the Churchill River above Red Head Rapids.

'Includes a gap from Jan. 1998 to Mar. 2002 inclusively.

${ }^{\mathrm{d}}$ Includes a gap from Jan. 1998 to Dec. 2007 inclusively.

stations are used sequentially to derive a continuous inflow record for the main stem Nelson River (Table 2). Daily hydrometric data on the main stem Moose River and the Abitibi, Kwetabohigan, and North French Rivers are summed to provide a time series of river discharge into James Bay for this regulated system. A 10-year gap on the Abitibi River at Onakawana is in-filled with data at the Otter Rapids generating station, whereas a 4-year gap on the Moose River is in-filled with the combined data from its two main tributaries, the Missinaibi and Mattagami Rivers, with the data adjusted for the missing contributing area in both cases.

Daily hydrometric data for La Grande Rivière downstream of the Acazi River archived by the Water Survey of Canada are used for January 1960 to September 1978, whereas daily data from HydroQuébec at the Robert-Bourassa (October 1979 to December 1994) and LG1 (January 1995 to December 2016) generating stations are employed thereafter. These data include a 1 year gap (corresponding to $1.7 \%$ of the total time series across the study period) from October 1978 to September 1979 that is in-filled using the following strategy. Data at two hydrometric stations in the La Grande system (de Pontois River and La Grande Rivière upstream of de Pontois River) that remain unregulated in the 1960s and 1970s are summed to provide a continuous time series of daily streamflow covering $58 \%$ of the basin's area
(Table 2). This time series is cross correlated (Pearson correlation coefficient: $r=0.985, P<0.001$, and $n=6,666$ ) with the observed daily discharge data for La Grande Rivière downstream of the Acazi River over July 1960 to September 1978. Lagged correlations of 1 to 31 days between the two time series show no improvement in the strength of their correspondence. Then using the combined daily data for La Grande Rivière upstream of the de Pontois River and the de Pontois River, the daily discharge for La Grande Rivière near its mouth for October 1978 to September 1979 is reconstructed on the basis of the derived linear regression assuming zero lag time. This approach provides perhaps the best estimates of La Grande Rivière's daily discharge to James Bay from October 1978 to September 1979 despite omitting anthropogenic influences on its flows during a period of dam construction and reservoir filling.

Use of these composite time series is necessary given our goal of capturing all water management influences (that evolve over time) including their cumulative impacts on daily streamflow input from La Grande Rivière, the Moose and Nelson/Churchill Rivers into Hudson Bay with a marine environment perspective. Identifying the individual role of all points of regulation of these rivers on downstream flows remains beyond the scope of this effort but will be targeted for future work. 


\section{2 | Methods}

\subsection{1 | Time series construction}

Time series of daily streamflow data (in $\mathrm{m}^{3} \mathrm{~s}^{-1}$ ) are constructed based on the available hydrometric data for each system of interest (see Section 3.1) and follows the approach outlined by Déry et al. (2005, 2016). For the Nelson River, data furthest downstream (i.e., at the Limestone generating station) are first used, but when unavailable (prior to construction), are replaced with those from the closest upstream hydrometric station while adjusting the data for the missing contributing area as necessary (Déry et al., 2005, 2016). These data capture CRD flows released at the Notigi control structure on the Rat River and the downstream Burntwood River starting in 1976 (Vörösmarty \& Sahagian, 2000). The concurrent hydrometric data for the Churchill River downstream of the Missi Falls control dam then reflect greatly diminished and regulated flows from this waterway into Hudson Bay. Once time series of daily discharge are constructed for each river, the data are summed for the four regulated and 17 unregulated rivers and used in the analyses.

\subsection{2 | Hydrograph and spectral analyses}

Several approaches are routinely used to infer hydrological changes in regulated rivers including comparisons of hydrographs preregulation and postregulation (e.g., Peters \& Buttle, 2010; Rosenberg et al., 1997; Woo et al., 2008), trend analyses of peak and/or low flows (e.g., Assani et al., 2006) or of naturalized versus observed (regulated) flows (Naik \& Jay, 2011; St. Jacques, Sauchyn, \& Zhao, 2010; Ye, Yang, \& Kane, 2003), and spectral or wavelet analyses (e.g., Smith, Turcotte, \& Isacks, 1998; Tongal, Demirel, \& Moradkhani, 2017; White, Schmidt, \& Topping, 2005). To infer flow alteration impacts on Hudson Bay river discharge, this study applies hydrographs and discrete Fourier transforms to assess the time and frequency domains, respectively. Hydrograph and spectral analyses are developed for each of the six decades of interest given the often abrupt and discrete nature of hydrological changes induced by water management (see Table 1). Hydrograph analysis uses daily discharge data and includes decadal changes in the interannual and day-to-day variability in flows as water management practices often leads to subtle changes not apparent at longer (e.g., monthly) timescales. The spectral analyses complement well the hydrographs by revealing the dominant time scales in flows and their evolution across the six decades of interest.

Thus, the annual cycles of the decadal (normalized) mean and coefficient of variation in daily discharge for the regulated and unregulated rivers spanning 1960-2016 are constructed and presented over the water year, taken here as October 1 to September 30 of the following calendar year. The analyses for each decade (1960-1969, 1970-1979, 1980-1989, 1990-1999, 2000-2009, and 2010-2016) of the study period thus provide their temporal evolution. Hydrographs are normalized through the division of the 1960-2016 mean daily discharge to facilitate cross comparisons between regulated and unregulated systems as well as across decades. Time series of the coefficient of variation in 7-day moving windows of daily discharge for both sets of rivers are also constructed and presented as decadal water year means to assess trends in day-to-day flow variability. Additional hydrographs that consider the days of the week are then produced for an early (1961-1988) and a late (19892016) 28-year period. Here, water year hydrographs of normalized daily mean discharge are developed for the regulated and unregulated rivers as well as their combined flows. A box and whisker plot then provides comparative statistics in normalized daily flows for the regulated and unregulated rivers for each day of the week for 1960 to 2016 with $n=2,974$ for Sunday through Thursday and $n=2,975$ for Friday and Saturday. Statistics included in the box and whisker plot are the mean, median, and range of minimum and maximum values within 1.5 times the interquartile range of the normalized daily river discharge. Here, normalization is again achieved by dividing daily flows with the corresponding 57-year mean value for the regulated and unregulated rivers. The nonparametric Wilcoxon signed rank (or Mann-Whitney) test then establishes whether the normalized regulated flows differ significantly $(P<0.05)$ from their unregulated counterparts. Here, we test whether the normalized regulated flows are greater than, or lesser than, the paired unregulated ones every day of the week and report $P$ values for each null hypothesis.

Next, decadal spectral analyses of the daily discharge for regulated and unregulated rivers are performed through discrete Fourier transforms using rectangular data windows in $x m G r a c e(c$. Non-linear regressions in the form $y=A x^{B}$ are then fitted to the log-transformed power spectra for return periods of 2 to 365 days. Cross correlations between the log-transformed power spectra for the regulated and unregulated rivers are also computed covering return periods of 2 to 365 days for all six decades of interest. To assess interannual variability in flow regulation, an additional set of discrete Fourier transforms is then performed on the daily discharge data for the regulated rivers for each year under study, then fitted with non-linear regressions in the form $y=A x^{B}$ to their log-transformed power spectra for return periods of 2 to 365 days. Coefficient B for each year is then plotted as a time series for 1960-2016 and assessed for trend using linear regression.

\section{4 | RESULTS}

\section{1 | Hydrograph analyses}

Decadal hydrographs of the normalized daily mean river discharge for the combined La Grande Rivière, Nelson/Churchill, and Moose Rivers across 1960-2016 show substantial departures from the nival regimes observed in the 17 mostly unregulated rivers, particularly from the 1980s onward (Figure 2a,b). The mean daily discharge for the unregulated rivers reaches a secondary peak in late October but then recedes gradually during fall and winter while increasing rapidly during spring in response to snowmelt driven run-off, with relatively little variation between decades. A similar pattern arises in the regulated rivers in the 1960s and 1970s, albeit with an attenuated seasonal cycle. Thereafter, the mean daily discharge for the regulated rivers remains nearly stable during all seasons apart from a period of enhanced flows during the spring freshet. There is a progression towards reduced seasonality and a near disappearance of the spring peak flows in the 2010s. The regulated rivers also show remarkable declines on the statutory holidays of Christmas and New Year's Days in response to greatly 


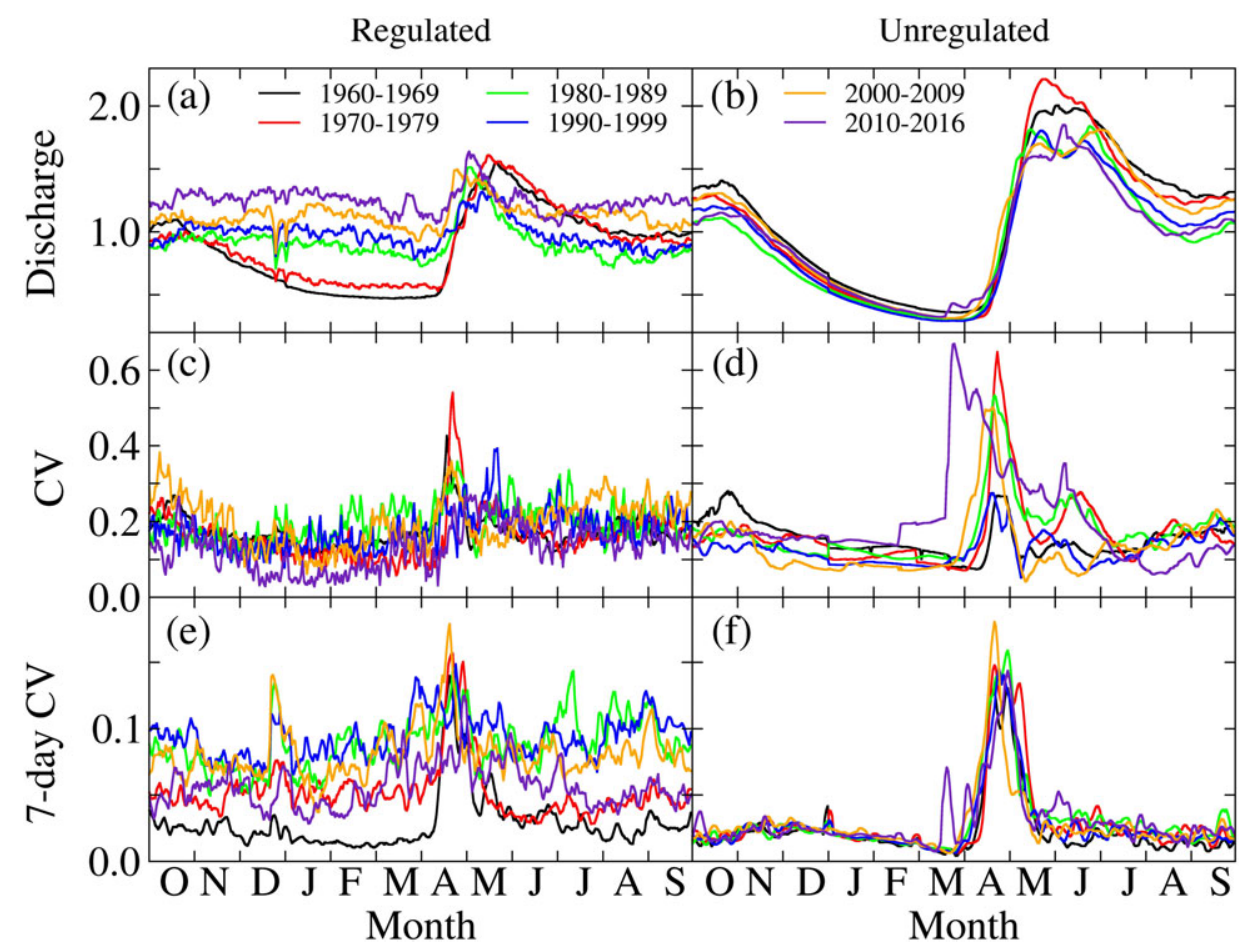

FIGURE 2 Decadal water year hydrographs of the (a and b) normalized mean, (c and d) coefficient of variation, and (e and f) coefficient of variation in 7-day moving windows of daily discharge for regulated and unregulated rivers, 1960-2016

diminished hydropower demand and production. These downward spikes in the regulated rivers' hydrographs emerge in the 1970 s and persist for the remainder of the study period. The hydrographs also exhibit noticeable day-to-day variations in mean daily discharge in association with flow regulation as these high-frequency oscillations are not observed in the unregulated rivers.

The coefficients of variation in daily discharge remain relatively stable throughout the water year averaging 0.17 for the regulated rivers for all six decades (Figure 2c). In contrast, there is strong seasonality in the coefficient of variation in daily discharge for the unregulated rivers, with low values in fall and winter followed by abrupt rises in spring associated with the interannual variability in the timing and intensity of the spring freshet (Figure 2d). Here, again, the hydrographs exhibit noticeable short-term fluctuations in regulated systems, features not seen in the unregulated rivers. Day-to-day variability in flows remains much higher in regulated rivers across all seasons, whereas their unregulated counterparts exhibit only high values in April and May (Figure 2e, f). Regulated rivers show greater day-to-day variability in flows in late December and early January owing to rapid fluctuations during the annual winter holidays. Increases in the 7-day coefficient of variation in moving windows of daily discharge occur in unregulated rivers owing to interannual variability in the magnitude and timing of the spring freshet but otherwise remain stable at $\sim 0.03$.

Constructing hydrographs for an early and a late period while considering the day of the week (Figure 3) reveals striking features not apparent in the previous analyses for regulated rivers (cf Figure 2a). A remarkable weekly cycle of low flows during weekends follows high flows during weekdays in the regulated rivers both in the early and late 28 -year periods. Indeed, daily discharge declines by $6 \%$ and $10 \%$ on Saturdays and Sundays, respectively, as well as $12 \%$ on Christmas

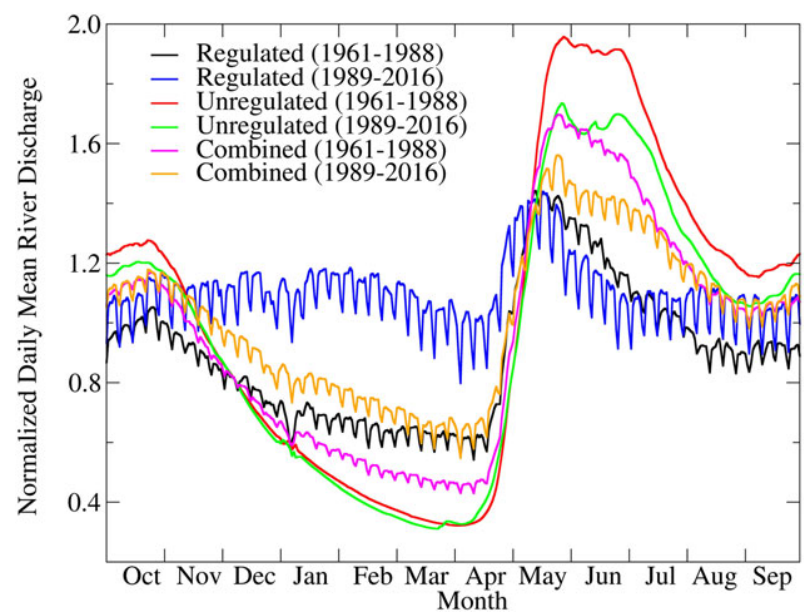

FIGURE 3 Water year hydrographs of the normalized mean daily discharge for regulated, unregulated, and combined rivers considering the day of the week during an early (1961-1988) and a late (1989-2016) period

and New Year's Days, relative to weekdays. This cyclical pattern remains absent in the mostly unregulated rivers across the study period. The combined hydrographs of the daily river discharge from the four highly regulated and 17 mostly unregulated rivers retain evidence of the weekly periodicity in flows. Surprisingly, the hydrograph for the combined unregulated and regulated rivers for 1989-2016 closely resembles that for the regulated rivers from 1961 to 1988 , highlighting the growing influence of regulation on the overall riverine input to Hudson Bay in recent decades. This is in stark contrast to the hydrographs for unregulated rivers that remain similar for the early and late periods. 
Statistics on the normalized daily discharge for each day of the week reveal the robust reductions in flows on weekends compared with weekdays in regulated rivers (Figure 4). In contrast, the mostly unregulated rivers show uniform statistics in normalized daily discharge each day of the week. The Wilcoxon signed rank test confirms the regulated flows decline significantly $(P<0.05)$ from the paired unregulated flows on weekends and rise significantly during weekdays apart from Mondays (Table 3). Substantially, lower ranges in normalized daily flows also emerge in regulated rivers relative to their unregulated counterparts.

\section{2 | Spectral analyses}

Discrete Fourier transforms of the time series of daily discharge for the highly regulated and mostly unregulated rivers show increasing power as the return periods expand for each decade, with peak values at the annual timescale (Figure 5). These peaks in the power spectra arise from the strong seasonality in flows associated with the nival regimes of Hudson Bay rivers. Spikes in the power spectra at the weekly timescale emerge in the regulated rivers in the 1970s onward, which arise from contrasts in hydropower production, and hence, water releases, during weekdays versus weekends. Secondary peaks in the power spectra at periods of 3.5 and 1.75 days originate from the decomposition of the discrete Fourier transforms at $1 / 2$ and $1 / 4$ wavelengths of the weekly timescale, and as such are harmonic artefacts of the spectral analyses. Similarly, secondary peaks in the power

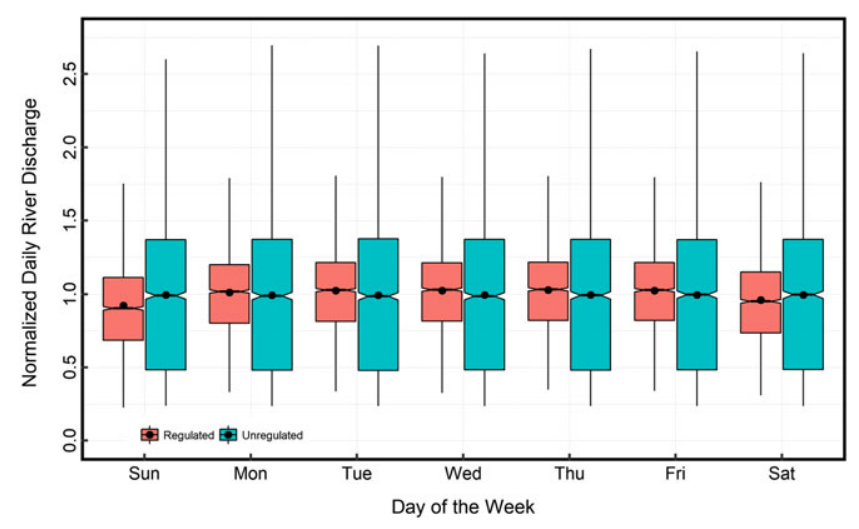

FIGURE 4 Box and whisker plot of the normalized daily river discharge for the regulated and unregulated rivers for each day of the week, 1960-2016. Black dots denote the mean, black horizontal lines represent the median, notches depict the $95 \%$ confidence interval of the medians, and the black vertical lines show the range of minimum and maximum values within 1.5 times the interquartile range of normalized daily river discharge spectra appear at 6-, 3-, and 1.5-month timescales from the decomposition of the annual cyclicity of river discharge.

In the 1960s, the power spectra for both sets of rivers exhibit distinct similarity with minimal power at short return periods and rapidly increasing power as the occurrence intervals lengthen. During this decade, the non-linear regressions exhibit coefficients $B=1.226$ and $B=1.180$ for the regulated and unregulated rivers, respectively (Table 4). In later decades, the analyses manifest a levelling of the frequency spectra for the highly regulated rivers as energy cascades towards shorter (<1 year) timescales. Indeed, slope magnitudes of non-linear regressions decline markedly (with coefficient $B=1.226$ for 1960-1969 diminishing to an average $B=0.730$ for 1990-2016) in the regulated rivers while they remain relatively stable (on average $B=1.405$ for 1960-2016) for the unregulated rivers (Table 4). Interestingly, peaks at the 1-week timescale in the spectra of regulated rivers surpass the power retained at the annual timescale in the 1980s onward. Cross correlations between the power spectra for the regulated and unregulated rivers spanning return periods of 2 to 365 days exceed 0.96 prior to the 1980 s but then decline to an average value of 0.57 thereafter (Table 4).

Performing non-linear regressions on the annual power spectra of daily discharge for the regulated rivers provides a time series of the associated B coefficients (Figure 6). Coefficients B decline from $\sim 1.37$ in the early 1960 s to a minimum of 0.65 in 1995 with values levelling off and averaging 0.82 thereafter. The linear regression $(y=-0.00972 x+20.2)$ executed on the coefficient $B$ time series yields a correlation coefficient $r=-0.778(P<0.05, n=57)$.

\section{5 | DISCUSSION}

Previous work on the impacts of regulation on streamflow input to Hudson and James Bays focused on seasonality changes (e.g., Anctil \& Couture, 1994; Déry et al., 2011; Prinsenberg, 1980) and impacts to the marine environment including estuarine salinity and circulation (Messier, Ingram, \& Roy, 1986), freshwater plumes and sea ice production (Ingram, Wang, Lin, Legendre, \& Fortier, 1996; Saucier \& Dionne, 1998), and Labrador Sea deep water formation and the thermohaline circulation (Leblond, Lazier, \& Weaver, 1996; Rennermalm, Wood, Weaver, Eby, \& Déry, 2007). By focusing on the daily discharge for the 21 largest river systems draining into Hudson and James Bays, this study highlights how regulation induces strong day-to-day variations in terrestrial freshwater inputs to the coastal ocean, with water releases controlled by hydropower demand and production. Significant reductions in regulated river discharge occur on weekends ( $6 \%$ on Saturdays and $10 \%$ on Sundays relative to weekday averages)

TABLE 3 Statistics ( $P$ values) of the Wilcoxon signed rank test performed on the 1960-2016 paired daily normalized flows for the regulated and unregulated rivers each day of the week (see Figure 4)

\begin{tabular}{llllllll} 
& Sun. & Mon. & Tue. & Wed. & Thu. & Fri. \\
Null hypothesis & $n=2,974$ & $n=2,974$ & $n=2,974$ & $n=2,974$ & $n=2,974$ & $n=2,975$ & $\begin{array}{l}\text { Sat. } \\
n=2,975\end{array}$ \\
\hline Reg. $<$ Unreg. & $7.88 \times 10^{-16}$ & 0.922 & 0.997 & 0.998 & 0.999 & 0.997 & $2.72 \times 10^{-5}$ \\
Reg. > Unreg. & 1.000 & 0.078 & 0.003 & 0.002 & 0.001 & 0.003 & 1.000 \\
\hline
\end{tabular}

Note. The number of samples is given by $n$ and bold values are statistically-significant $(P<0.05)$. 
1960-1969

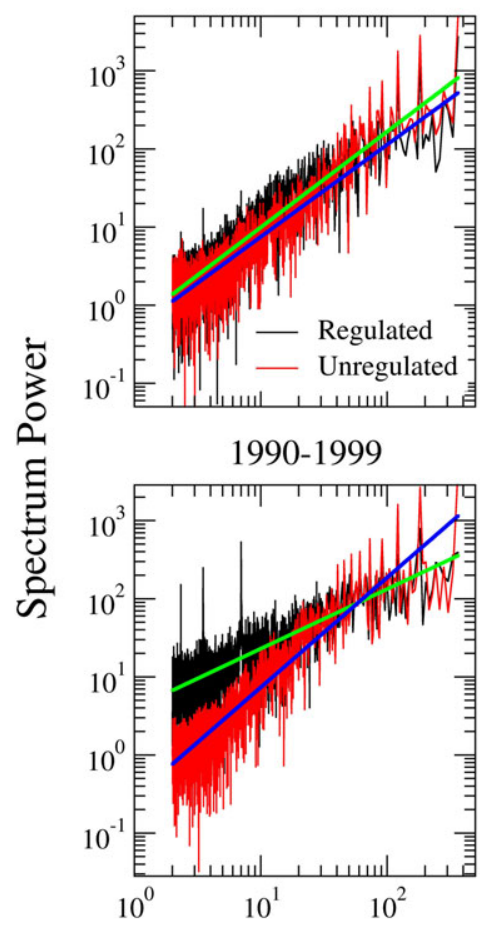

1970-1979

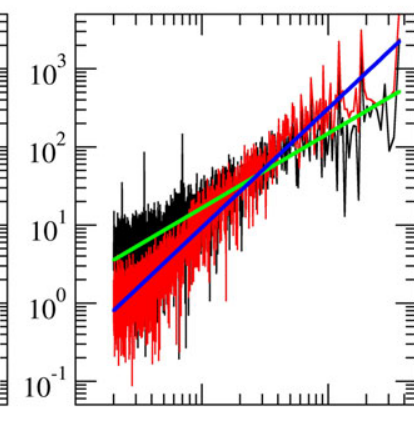

2000-2009

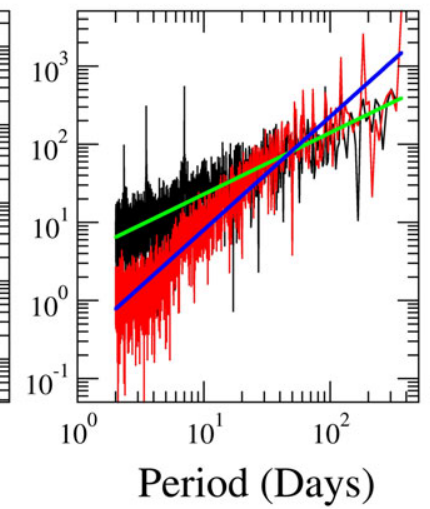

1980-1989

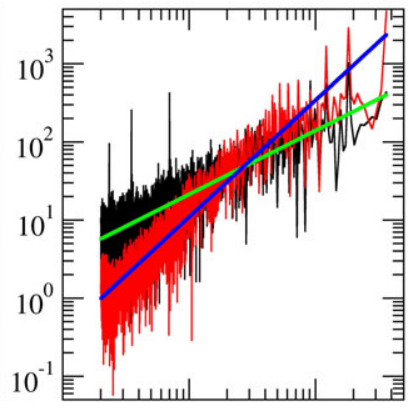

2010-2016

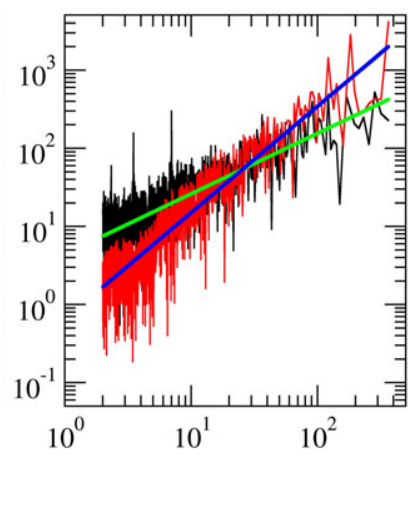

FIGURE 5 Decadal spectral analyses of daily discharge for regulated and unregulated rivers, 1960-2016. Thick green and blue lines denote nonlinear regressions (with statistics compiled in Table 4) performed on the power spectra covering return periods of 2 to 365 days for the regulated and unregulated rivers, respectively

TABLE 4 Statistics of the non-linear regressions (in the form $y=A x^{B}$, equivalent to $\log y=\log A+B \log x$, where coefficient $B$ is the slope of the equation) and cross correlations $\left(r_{R U}\right)$ performed on the decadal power spectra covering return periods of 2 to 365 days for the regulated and unregulated rivers (see Figure 5)

\begin{tabular}{|lllllll|}
\hline Rivers & Decade & $n$ & Coeff. A & Coeff. B & $r$ & $r_{R U}$ \\
\hline Regulated & $1960-1969$ & 1,816 & 0.591 & 1.226 & 0.861 & 0.980 \\
& $1970-1979$ & 1,816 & 1.850 & 0.953 & 0.787 & 0.963 \\
\hline & $1980-1989$ & 1,816 & 3.270 & 0.815 & 0.740 & 0.687 \\
\hline $1990-1999$ & 1,816 & 3.972 & 0.763 & 0.722 & 0.556 \\
\hline & $2000-2009$ & 1,816 & 3.766 & 0.787 & 0.727 & 0.500 \\
\hline Unregulated & $1910-2016$ & 1,271 & 4.412 & 0.773 & 0.740 & 0.550 \\
\hline & $1970-1969$ & 1,816 & 0.497 & 1.180 & 0.853 & 0.980 \\
\hline $1980-1989$ & 1,816 & 0.353 & 1.494 & 0.905 & 0.687 \\
\hline $1990-1999$ & 1,816 & 0.290 & 1.405 & 0.886 & 0.556 \\
\hline $2000-2009$ & 1,816 & 0.288 & 1.449 & 0.900 & 0.500 \\
\hline $2010-2016$ & 1,271 & 0.654 & 1.361 & 0.892 & 0.550 \\
\hline
\end{tabular}

Note. The number of samples is given by $n$ and the correlation coefficients by $r$ and $r_{R U}$, all statistically-significant at $P<0.001$.

and on national statutory holidays such as Christmas and New Year's Days. The hydrographs while considering the day of the week (Figure 3) highlight these striking features that are otherwise not observed prior to major regulation or masked in the water year hydrographs (cf Figure 2a). This weekly cyclicity in flows can be partly

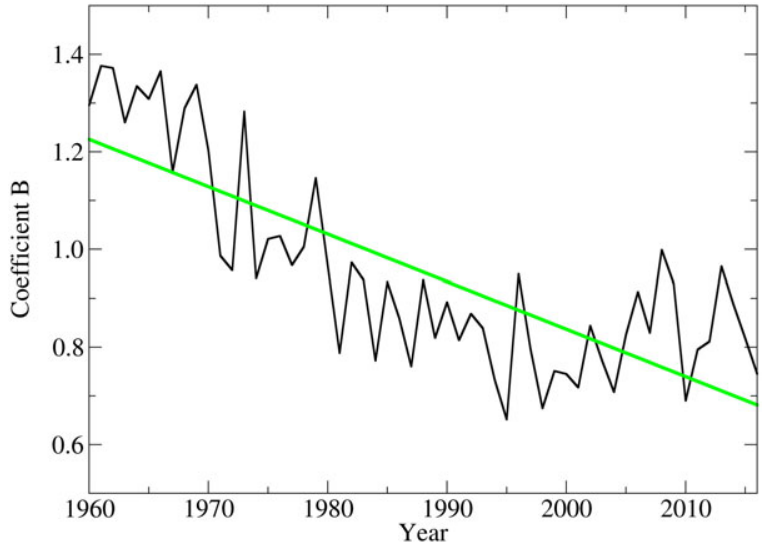

FIGURE 6 Time series of the coefficient B from non-linear regressions in the form $y=A x^{B}$ performed on the annual power spectra of daily discharge for the regulated rivers, 1960-2016. The thick green line denotes the linear regression with Pearson correlation coefficient $r=-0.778, P<0.05, n=57$

attributed to waning demands for hydropower on weekends and statutory holidays by commercial and industrial users that account for 40.3\% and $49.9 \%$ of Manitoba Hydro's and Hydro-Québec's recent sales and production, respectively, with residential clients and export markets accounting for the remainder (Hydro-Québec, 2016; Manitoba Hydro, 2017b). The appearance of such periodicity in flows in highly regulated systems confirms that hydroelectric generation now plays a dominant control in daily freshwater water inputs to Hudson and James Bays. 
The spectral analyses and corresponding non-linear regressions (Figures 5 and 6) provide additional insights on the dominant timescales of the variability in inflows to Hudson Bay. Although the power spectra for the regulated and unregulated rivers appear nearly identical in the 1960s, the emergence thereafter of spikes at the weekly timescale and a levelling of the power spectra (identified by the lower values of $B$ coefficients in the non-linear regressions) mark departures in the hydrological regimes of the regulated rivers from their unregulated counterparts. This transition from a relatively strong red noise power spectrum in the 1960s to white noise power spectra in the following decades in the regulated rivers mimics differences between snow-dominated rivers with highly periodic, annual spring freshets versus rainfall-dominated rivers with highly irregular precipitation events (cf figure 4 of Smith et al., 1998). The reduction in values of the coefficient $B$ for the non-linear regressions applied to the power spectra of the regulated rivers reveals the cascade of energy to shorter timescales of variability associated with flow regulation with the loss of the robust seasonality typically seen in nival regimes. The diminished intensity of the spikes in power spectra at the weekly timescale and its subharmonics (Figure 5) along with slightly higher values of the coefficient B since 1995 (Figure 6) suggest a recent attenuation of the contrasting weekday versus weekend flows. These features in the power spectra likely arise from increasing hydropower demands on weekends relative to weekdays perhaps tied to intensifying commercial and industrial activities on weekends since the mid-1990s. Indeed, a time series of the mean annual ratio of weekend to weekday flows exhibits a sharp rise from a minimum of 0.79 in 1998 to 0.95 in 2016 (Figure 7). Thus, emerging trends in hydroelectric demand and generation will continue to alter the weekly to monthly timing and volume of inflows to Hudson Bay in the coming decades.

Given the power grids managed by Manitoba Hydro, Ontario Power Generation, and Hydro-Québec are interconnected to their American counterparts, the origin of daily and seasonal fluctuations in freshwater inputs to Hudson and James Bays may extend well beyond the boundaries of the watersheds being managed for hydropower production. Indeed, hydropower demand across the northern United States may be contributing to some of the observed variations in daily and seasonal flows in the La Grande Rivière, Nelson/Churchill, and Moose Rivers. As an example, a pronounced wintertime cold spell

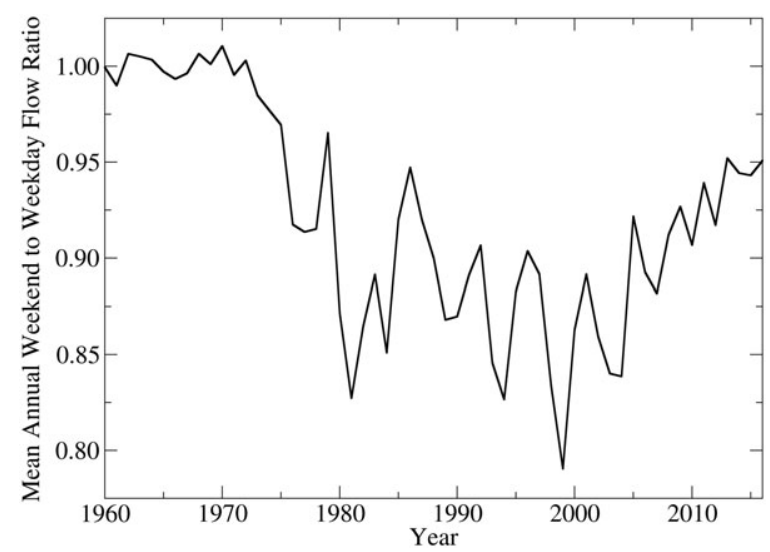

FIGURE 7 Mean annual ratio of weekend to weekday flows for the regulated rivers, 1960-2016 or summertime heat wave in the northern United States could increase demand for hydropower from Canadian utility companies even when provincial demands remain low. Conversely, the interconnections to southern systems that experience peak demands during summer may temper the seasonal shifting of flows required by a northern hydropower system. Interconnections thus enable more Canadian hydroelectric generation during summer for export to other markets and imports during winter when provincial power demand peaks, attenuating the need for higher winter flows. Emerging "anthropogenic teleconnections" through power grid interconnectivity superimposed on atmospheric teleconnections (e.g., the Arctic Oscillation; Déry \& Wood, 2004) may now be influencing Hudson Bay streamflow input.

There is evidence of greater day-to-day fluctuations from the annual cycles of 7-day coefficients of variation in daily regulated discharge in recent decades (see Figure 2e). This could be interpreted as a decrease in the predictability in daily river discharge and net freshwater import to the coastal ocean. In fact, given the highly periodic nature of those variations at the weekly timescale, some measure of predictability arises from water management in the Nelson/Churchill River, Moose River, and La Grande Rivière. This effect may be most pronounced on weekends and statutory holidays (e.g., Christmas and New Year's Days). Thus, real-time hydrological models coupled to system optimization models benefit by incorporating such measures of predictability in forecasting future hydrological conditions of river reaches downstream from hydroelectric facilities. This also suggests that global and regional climate model projections of the potential future state and fate of the Hudson Bay system require consideration of anthropogenic activities such as the regulation and diversion of flows, reservoir filling, and water ageing when looking at seasonal patterns and interannual variability (e.g., Vörösmarty \& Sahagian, 2000). To that end, a suite of simulations using the Arctic-HYPE hydrological model (Andersson, Pechlivanidis, Gustafsson, Donnelly, \& Arheimer, 2015; MacDonald et al., 2018) driven by historical and projected climatic conditions is being undertaken by the authors to disentangle the effects of flow regulation and climate change on the contemporary and potential future freshwater budget of the Hudson Bay complex.

\section{6 | CONCLUSIONS}

This study contributes to the literature on the emerging importance of human interference including hydroelectric developments on global river discharge (e.g., Arheimer, Donnelly, \& Lindström, 2017; Haddeland et al., 2014; Rosenberg et al., 1997). Indeed, many boreal, snow-dominated systems now exhibit stronger influences from regulation than climate change (Arheimer et al., 2017). For instance, snowfed rivers in Sweden exhibit a similar proportion (19\%) of seasonal flow redistribution from regulation and late 21st century climate change with an earlier onset (by 1 month) of peak flows (Arheimer et al., 2017). The La Grande Rivière, Nelson/Churchill, and Moose Rivers clearly manifest this pattern with flow regulation significantly affecting daily to seasonal discharge into Hudson and James Bays. These four rivers, among the largest by annual flow volumes in the Hudson Bay drainage, have been harnessed along their main stems 
and/or major tributaries for their hydroelectric potential during the past half-century, inducing greater day-to-day fluctuations and modifying the seasonality of their natural nival regimes. A key question then is whether this alters the marine environment and ecosystem of Hudson Bay through salinity and water temperature modifications, sea ice production and melt, and biochemical processes, which is an ongoing goal for our collaborators in the BaySys project. As such, this study provides guidance for ocean and sea ice modellers on the nature of river discharge inputs to Hudson Bay including their temporal scales of variability.

\section{ACKNOWLEDGMENTS}

Thanks to the Water Survey of Canada and its provincial and territorial partners, Manitoba Hydro, Ontario Power Generation, and HydroQuébec for providing hydrometric data and the Natural Sciences and Engineering Research Council of Canada, Manitoba Hydro, and partners through funding of the BaySys project. Thanks to Bunu GauliSharma and Aseem Sharma (UNBC) for preparing Figures 1 and 4, respectively, Shane Wruth (Manitoba Hydro), Sabrina Cardin Ouellette, Samer Alghabra, and Jonathan Guidi (Hydro-Québec) for compiling data for the Nelson River and La Grande Rivière, respectively, and researchers at Manitoba Hydro, Ontario Power Generation and Hydro-Québec for logistical support and review of the paper. Comments from Mike Vieira, Shane Wruth, Jason Westmacott, Karl Reznichek, and Kevin Gawne (Manitoba Hydro), Siraj UI Islam (UNBC), Francis Zwiers (Pacific Climate Impacts Consortium), Scott Jasechko (University of California Santa Barbara), and two anonymous reviewers much improved the quality of the paper.

\section{AUTHOR CONTRIBUTIONS}

S. J. D. designed the study, extracted hydrometric data and constructed time series of daily river discharge for all rivers, computed the hydrographs, performed the statistical and spectral analyses, and drafted figures with support from T. A. S., M. K. M., K. A. K., and C. G. S. J. D. wrote the manuscript with contributions from all coauthors and all contributed to manuscript refinement and revisions.

\section{ORCID}

Stephen J. Déry (D) http://orcid.org/0000-0002-3553-8949

Tricia A. Stadnyk (D) http://orcid.org/0000-0002-2145-4963

Matthew K. MacDonald (D) http://orcid.org/0000-0002-8794-4404

Kristina A. Koenig (D) http://orcid.org/0000-0002-1570-3820

Catherine Guay (D) http://orcid.org/0000-0003-3772-7791

\section{REFERENCES}

Anctil, F., \& Couture, R. (1994). Impacts cumulatifs du développement hydro-électrique sur le bilan d'eau douce de la baie d'Hudson. Canadian Journal of Civil Engineering, 21, 297-306. https://doi.org/10.1139/194031

Andersson, J. C. M., Pechlivanidis, I. G., Gustafsson, D., Donnelly, C., \& Arheimer, B. (2015). Key factors for improving large-scale hydrological model performance. European Water, 49, 77-88.

Arheimer, B., Donnelly, C., \& Lindström, G. (2017). Regulation of snow-fed rivers affects flow regimes more than climate change. Nature Communications, 8, 62. https://doi.org/10.1038/s41467-017-00092-8
Assani, A. A., Stichelbout, E., Roy, A. G., \& Petit, F. (2006). Comparison of impacts of dams on the annual maximum flow characteristics in three regulated hydrologic regimes in Québec (Canada). Hydrological Processes, 20, 3485-3501. https://doi.org/10.1002/hyp.6150

Benke, A. C., \& Cushing, C. E. (Eds.) (2010). Field guide to rivers of North America. Elsevier: Academic. 459 pp

Bring, A., Fedorova, I., Dibike, Y., Hinzman, L., Mård, J., Mernild, S. H., ... Woo, M.-K. (2016). Arctic terrestrial hydrology: A synthesis of processes, regional effects, and research challenges. Journal of Geophysical Research, Biogeosciences, 121, 621-649. https://doi.org/ 10.1002/2015JG003131

Déry, S. J., Mlynowski, T. J., Hernández-Henríquez, M. A., \& Straneo, F. (2011). Interannual variability and interdecadal trends in Hudson Bay streamflow. Journal of Marine Systems, 88, 341-351. https://doi.org/ 10.1016/j.jmarsys.2010.12.002

Déry, S. J., Stadnyk, T. A., MacDonald, M. K., \& Gauli-Sharma, B. (2016). Recent trends and variability in river discharge across northern Canada. Hydrology and Earth System Sciences, 20, 4801-4818. https://doi.org/ 10.5194/hess-20-4801-2016

Déry, S. J., Stieglitz, M., McKenna, E. C., \& Wood, E. F. (2005). Characteristics and trends of river discharge into Hudson, James, and Ungava Bays, 1964-2000. Journal of Climate, 18, 2540-2557. https://doi.org/ $10.1175 / \mathrm{JCLI} 3440.1$

Déry, S. J., \& Wood, E. F. (2004). Teleconnection between the Arctic Oscillation and Hudson Bay river discharge. Geophysical Research Letters, 31, L18205. https://doi.org/10.1029/2004GL020729

Dynesius, M., \& Nilsson, C. (1994). Fragmentation and flow regulation of river systems in the northern third of the world. Science, 266, 753-762. https://doi.org/10.1126/science.266.5186.753

Haddeland, I., Heinke, J., Biemans, H., Eisner, S., Flörke, M., Hanasaki, N., ... Wisser, D. (2014). Global water resources affected by human interventions and climate change. Proceedings of the National Academy of Sciences of the USA, 111, 3251-3256. https://doi.org/10.1073/ pnas. 1222475110

Hernández-Henríquez, M. A., Mlynowski, T. J., \& Déry, S. J. (2010). Reconstructing the natural streamflow of a regulated river: A case study of La Grande Rivière, Québec, Canada. Canadian Water Resources Journal, 35, 301-316. https://doi.org/10.4296/cwrj3503301

Hydro-Québec. (2008). Eastmain-1-A and Sarcelle Powerhouses and Rupert Diversion: A hydroelectric project for present and future generations (unpublished report), $28 \mathrm{pp}$.

Hydro-Québec. (2016). [Available at http://www.hydroquebec.com/publications/fr/documents-entreprise/rapport-annuel.html]

Hydro-Québec. (2017). [Available at http://www.hydroquebec.com/generation/.]

Ingram, R. G., Wang, J., Lin, C., Legendre, L., \& Fortier, L. (1996). Impact of freshwater on a subarctic coastal ecosystem under seasonal sea ice (southeastern Hudson Bay, Canada). I. Interannual Variability and Predicted Global Warming Influence on River Plume Dynamics and Sea Ice. Journal of Marine Systems, 7, 221-231. https://doi.org/10.1016/ 0924-7963(95)00006-2

Lajoie, F., Assani, A. A., Roy, A. G., \& Mesfioui, M. (2007). Impacts of dams on monthly flow characteristics. The influence of watershed size and seasons. Journal of Hydrology, 334, 423-439. https://doi.org/ 10.1016/j.jhydrol.2006.10.019

Leblond, P. H., Lazier, J. R., \& Weaver, A. J. (1996). Can regulation of freshwater runoff in Hudson Bay affect the climate of the North Atlantic? Arctic, 49, 348-355.

Leconte, R., Pietroniro, A., Peters, D. L., \& Prowse, T. D. (2001). Effects of flow regulation on hydrologic patterns of a large, inland delta. Regulated Rivers: Research \& Management, 17, 51-65. https://doi.org/ 10.1002/1099-1646(200101/02)17:1<51::AID-RRR588>3.0.CO;2-V

MacDonald, M. K., Stadnyk, T. A., Déry, S. J., Braun, M., Gustafsson, D., Isberg, K., \& Arheimer, B. (2018). Impacts of $1.5^{\circ} \mathrm{C}$ and $2.0^{\circ} \mathrm{C}$ warming on pan-Arctic river discharge into the Hudson Bay Complex through 
2070. Geophysical Research Letters, 45, 7561-7570. https://doi.org/ 10.1029/2018GL079147

Macdonald, R. W., \& Kuzyk, Z. Z. A. (2011). The Hudson Bay system: A northern inland sea in transition. Journal of Marine Systems, 88, 337-340. https://doi.org/10.1016/j.jmarsys.2011.06.003

Manitoba Hydro. (2017a). [Available at https://www.hydro.mb.ca/corporate/facilities/generating_stations.shtml.]

Manitoba Hydro. (2017b). [Available at https://www.hydro.mb.ca/corporate/electricity_exports.shtml.]

Messier, D., Ingram, R. G., \& Roy, D. (1986). Physical and biological modifications in response to La Grande hydroelectric complex. In I. P. Martini (Ed.), 403-424 Canadian Inland Seas. New York: Elsevier.

Naik, P. K., \& Jay, D. A. (2011). Distinguishing human and climate influences on the Columbia River: Changes in mean flow and sediment transport. Journal of Hydrology, 404, 259-277. https://doi.org/ 10.1016/j.jhydrol.2011.04.035

Ontario Power Generation. (2017). [Available at https://www.opg.com/ generating-power/hydro/.]

Peters, D. L., \& Buttle, J. M. (2010). The effects of flow regulation and climatic variability on obstructed drainage and reverse flow contribution in a northern river-lake-delta complex, Mackenzie Basin headwaters. River Research and Applications, 26, 1065-1089. https://doi.org/ 10.1002/rra.1314

Peters, D. L., \& Prowse, T. D. (2001). Regulation effects on the lower Peace River, Canada. Hydrological Processes, 15, 3181-3194. https://doi.org/ 10.1002/hyp.321

Prinsenberg, S. J. (1980). Man-made changes in the freshwater input rates of Hudson and James Bays. Canadian Journal of Fisheries and Aquatic Sciences, 37, 1101-1110. https://doi.org/10.1139/f80-143

Rennermalm, A. K., Wood, E. F., Weaver, A. J., Eby, M., \& Déry, S. J. (2007) Relative sensitivity of the Atlantic meridional overturning circulation to river discharge into Hudson Bay and the Arctic Ocean. Journal of Geophysical Research, 112. G04S48. DOI: https://doi.org/10.1029/ 2006JG000330

Rosenberg, D. M., Berkes, F., Bodaly, R. A., Hecky, R. E., Kelly, C. A., \& Rudd, J. W. M. (1997). Large-scale impacts of hydroelectric development. Environmental Reviews, 5, 27-54. https://doi.org/10.1139/a97001

Roy, D., \& Messier, D. (1989). A review of the effects of water transfers in the La Grande Hydroelectric Complex (Québec, Canada). River Research and Applications, 4, 299-316.
Saucier, F., \& Dionne, J. (1998). A 3-D coupled ice-ocean model applied to Hudson Bay, Canada: The Seasonal Cycle and Time-Dependent Climate Response to Atmospheric Forcing and Runoff. Journal of Geophysical Research, 103, 27689-27705. https://doi.org/10.1029/ 98JC02066

Smith, L. C., Turcotte, D. L., \& Isacks, B. L. (1998). Stream flow characterization and feature detection using a discrete wavelet transform. Hydrological Processes, 12, 233-249. https://doi.org/10.1002/ (SICI)1099-1085(199802)12:2<233::AID-HYP573>3.0.CO;2-3

St. Jacques, J.-M., Sauchyn, D. J., \& Zhao, Y. (2010). Northern Rocky Mountain streamflow records: Global warming trends, human impacts or natural variability? Geophysical Research Letters, 37. L06407. doi: https://doi.org/10.1029/2009GL042045

Tongal, H., Demirel, M. C., \& Moradkhani, H. (2017). Analysis of daminduced patterns on river flow dynamics. Hydrological Sciences Journal, 62, 626-641. https://doi.org/10.1080/02626667.2016.1252841

United States Geological Survey (USGS). (2017). [Available at https:// water.usgs.gov/edu/hybiggest.html.]

Vörösmarty, C. J., \& Sahagian, D. (2000). Anthropogenic disturbance of the terrestrial water cycle. Bioscience, 50, 753-765. https://doi.org/ 10.1641/0006-3568(2000)050[0753:ADOTTW]2.0.CO;2

Water Survey of Canada. (2017). [Available at http://www.ec.gc.ca/rhcwsc/.]

White, M. A., Schmidt, J. C., \& Topping, D. J. (2005). Application of wavelet analysis for monitoring the hydrologic effects of dam operation: Glen Canyon Dam and the Colorado River at Lees Ferry, Arizona. River Research and Applications, 21, 551-565. https://doi.org/10.1002/rra.827

Woo, M., Thorne, R., Szeto, K., \& Yang, D. (2008). Streamflow hydrology in the boreal region under the influence of climate and human interference. Philosophical Transactions of the Royal Society B, 363, 2251-2260.

Ye, B., Yang, D., \& Kane, D. L. (2003). Changes in Lena River streamflow hydrology: Human impacts versus natural variations. Water Resources Research, 39(7), 1200. https://doi.org/10.1029/2003WR001991

How to cite this article: Déry SJ, Stadnyk TA, MacDonald MK, Koenig KA, Guay C. Flow alteration impacts on Hudson Bay river discharge. Hydrological Processes. 2018;1-12. https://doi.org/10.1002/hyp.13285 